\title{
An Assessment Of Foreign Direct Investments Effects In Albania
}

\author{
Llesh LLESHAJ \\ $\mathrm{PhD}$ candidate, Pedagogue, Department of Finance, \\ Faculty of Economy, University of Tirana, email: Ileshlleshaj@feut.edu.al \\ Visar MALAJ, PhD \\ Lecturer of Economics, Economics Department, \\ Faculty of Economy, University of Tirana, email: visarmalaj@feut.edu.al \\ Arjan TUSHAJ, PhD \\ Lecturer of Economics, Economics Department, \\ Faculty of Economy, University of Tirana, email: arjantushaj@feut.edu.al
}

DOI:10.5901/mjss.2014.v5n22p218

\begin{abstract}
In a country like Albania, Foreign Direct Investments (FDIs) are the main priority for economic growth and especially where they focus. Many developing countries (including our country) view these investments as unique opportunities to develop faster and increase the competition and the level of exports. We try to find in this work a link between FDIs and economic growth in Albania. We estimate in this framework some quantitative models, with some economic indicators as independent variables and with the level of foreign direct investment in Albania as a dependent variable. In this context, FDIs are dependent on many factors which can be classified as quantitative variables, like economic growth, average wages, foreign trade, GDP per capita, taxes, etc., and qualitative variables, like Index of Economic Freedom, infrastructure, secure internet servers, etc.
\end{abstract}

Key words: FDls, developing economies, FDls flows, economic growth.

\section{INTRODUCTION}

Foreign Direct Investments, in their classical form, are defined as a physical investment that a foreign entrepreneur does in a country other than his country of origin, by engaging his financial funds with the purpose of having returns over this investment. FDIs are investments that affect the growth of economical and political stability between the country of origin and the hosting country. Foreign investors benefit from certain facilities that are offered to them by the hosting country (that are not offered by the country of origin) and in return, they bring long-term investments to the hosting country. FDIs have become very quickly a very important element of growth, development and global economical integration during the 90's, (UNCTAD, 2003).

FDIs bring in the hosting country companies with a different culture and capacity, compared with existing companies in that market, by bringing change, even radical sometimes, in the way goods and services are perceived and offered and of standards in the entire sector. All of this, effects the economical growth in general, but in countries like Albania, they increase first of all the employment. The employment growth in the production industry has been one of the most obvious benefits from FDIs for Eastern European countries during 1995 - 2010 (UNCTAD, Trade and Development Report 2012, pg. 86-93). Seen in this context, (as per reasons mentioned above) both country of origin and hosting country have economical development and growth.

Countries that respect authorship and patent rights, invest in research and development and use innovative technology and software's, have a focus in building and increasing capacities of their working force, become very soon major attractions for foreign investors. It's related to many advantages in the country's market and also according to competiveness in global markets. 
The effects of FDIs in the economy are multidimensional; FDIs in Albania are in the form of shared equity, in almost 80\%1 of cases, and in the form of initial capital and additional contributions. The first full legal basis in Albania concerning FDIs are founded under the Law No.7764, 2.11.1993, "On Foreign Investments" with a status derived from Law No.7594, 4.8.1992, "On Foreign Investments". Legislation in Albania make sure that foreign investors and local investors have equal rights. We can find in the table below some main practical advantages and disadvantages of FDIs in Albania.

Tab.1: $\quad$ Impact of FDIs in developing economies (the case of Albania):

The Effect of FDIs in developing economies

\begin{tabular}{|c|c|}
\hline Advantage & Disadvantage \\
\hline $\begin{array}{l}\text { FDIs are pure funding sources, even for the development } \\
\text { of projects of large scale. } \\
\text { They offer new opportunities of development (in } \\
\text { preparation of agreements with foreign clients, due to } \\
\text { entering in the international market). } \\
\text { FDIs are long-term and strategic investments (the focus } \\
\text { of the company is the long-term activity with development } \\
\text { perspectives). } \\
\text { High performance (FDIs are investments that influence } \\
\text { the use of new technology, new capacities and more } \\
\text { efficiency). } \\
\text { Increase of employment and quality of management in the } \\
\text { hosting country. } \\
\text { Reduction of the cost of capital (foreign investors can } \\
\text { increase the amount of capital in international markets by } \\
\text { reducing the level of capital cost). } \\
\text { They increase significantly the quality aspect, both for } \\
\text { goods and services, making it comparable to the } \\
\text { standards of developed countries. }\end{array}$ & $\begin{array}{l}\text { Repatriation of profits by foreign owners, given that FDIs } \\
\text { in Albania have } 80 \% \text { of their stock in shared capital, a } \\
\text { large proportion of profit (if net profit is expected to be } \\
\text { positive) will go out of country as a dividend, meaning that } \\
\text { we will have a movement of capital from our country to the } \\
\text { countries of origin. } \\
\text { Negative impact in current account (repatriation of profits; } \\
\text { outflows can also be funds of financial nature for various } \\
\text { non-resident creditors in Albania, e.g., in } 2008 \text { 'Albanian } \\
\text { Mobile Communication' gave a loan to the parent } \\
\text { company in Greece). } \\
\text { The deficit of domestic capital or foreign capital (this is not } \\
\text { even potentially problematic for Albania). If foreign capital } \\
\text { exceeds certain limits or parameters of an economy in } \\
\text { equilibrium, it can create an economic dependency on } \\
\text { foreign investors. }\end{array}$ \\
\hline
\end{tabular}

According to official statistics, the average annual of stock of foreign investments in Albania for the years $2001-2011$ is spread in these countries of origin:

Tab. 2: $\quad$ The average annual stock or FDIs in Albania, 2001 - 2011.

\begin{tabular}{|l|l|l|}
\hline Country of origin & Total in millions Euro & Percentage over the total \\
\hline Greece & 558.4 & $23.6 \%$ \\
\hline Italy & 326.6 & $13.8 \%$ \\
\hline Austria & 280.2 & $11.8 \%$ \\
\hline Turkey & 228.4 & $9.6 \%$ \\
\hline Netherlands & 227.8 & $9.6 \%$ \\
\hline Canada & 194.2 & $8.2 \%$ \\
\hline Switzerland & 79.0 & $3.3 \%$ \\
\hline Germany & 72.2 & $3.0 \%$ \\
\hline Other & 405.2 & $17.1 \%$ \\
\hline
\end{tabular}

\footnotetext{
${ }^{1}$ National Bank of Albania, "Report on Foreign Direct Investments, 2011".
} 
Source: Bank of Albania, 2013.

The average annual stock of FDIs in Albania for the years 2001 - 2011 is concentrated mostly in the sectors of 'Financial Intermediation', 'Transport, warehousing and communications' and 'Refining Industry'. We can see table 3 for a more detailed classification.

Tab. 3: Dispersion of FDls for each sector, $2001-2011$.

\begin{tabular}{|l|l|l|}
\hline Economy sector & $\begin{array}{l}\text { Total in million } \\
\text { Euro }\end{array}$ & $\begin{array}{l}\text { Percentage over } \\
\text { the Total }\end{array}$ \\
\hline Financial Intermediation & 627.4 & $26.5 \%$ \\
\hline Transport, warehousing and communications & 424.4 & $17.9 \%$ \\
\hline Refining Industry & 392.4 & $16.5 \%$ \\
\hline Productions Industry & 228.4 & $9.6 \%$ \\
\hline Trade (big and small quantities) & 212.6 & $9.0 \%$ \\
\hline Constructions & 186.0 & $7.8 \%$ \\
\hline Production and delivery of electricity & 88.2 & $3.7 \%$ \\
\hline Hotels and restaurants & 82.6 & $3.5 \%$ \\
\hline Other & 130 & $5.5 \%$ \\
\hline
\end{tabular}

Source: Bank of Albania, 2013.

\section{EMPIRICAL RESULTS}

In this section, we analyze several economic indicators, which are related to the development and growth of FDls flows. We consider time series data with an annual period, from 2001 to 2011.

Tab. 4: Annual empirical data for Albania, 2001 - 2011.

\begin{tabular}{|l|l|l|l|l|l|l|l|l|}
\hline Year & $\begin{array}{l}\text { FDIs } \\
\text { net } \\
\text { inflows } \\
\text { IGDP }\end{array}$ & $\begin{array}{l}\text { Economic } \\
\text { Growth }\end{array}$ & $\begin{array}{l}\text { OP/GDP } \\
\text { (foreign } \\
\text { trade) }\end{array}$ & $\begin{array}{l}\text { Average } \\
\text { monthly } \\
\text { wage } \\
\text { ALL) }\end{array}$ & $\begin{array}{l}\text { Index of } \\
\text { (inconomic } \\
\text { Freedom }\end{array}$ & $\begin{array}{l}\text { Secure } \\
\text { Internet } \\
\text { servers for } \\
100 \\
\text { inhabitants }\end{array}$ & $\begin{array}{l}\text { Gross } \\
\text { capital } \\
\text { formation } \\
\text { /GDP }\end{array}$ & $\begin{array}{l}\text { Fiscal } \\
\text { Burden }\end{array}$ \\
\hline 2001 & 0.0507 & 0.07 & 0.60 & 14,820 & 56.60 & 1.00 & 0.2755 & 0.1017 \\
\hline 2002 & 0.0303 & 0.03 & 0.67 & 16,541 & 56.80 & 1.00 & 0.2449 & 0.1084 \\
\hline 2003 & 0.0315 & 0.06 & 0.67 & 18,522 & 56.80 & 1.00 & 0.2344 & 0.1197 \\
\hline 2004 & 0.0457 & 0.06 & 0.65 & 19,039 & 58.50 & 2.00 & 0.2384 & 0.1194 \\
\hline 2005 & 0.0313 & 0.06 & 0.68 & 19,993 & 57.80 & 1.00 & 0.2360 & 0.1399 \\
\hline 2006 & 0.0356 & 0.05 & 0.74 & 21,842 & 60.30 & 5.00 & 0.2505 & 0.1494 \\
\hline 2007 & 0.0609 & 0.06 & 0.84 & 27,350 & 61.40 & 8.00 & 0.2976 & 0.1304 \\
\hline 2008 & 0.0957 & 0.06 & 0.86 & 34,277 & 62.40 & 15.00 & 0.3213 & 0.1471 \\
\hline 2009 & 0.1108 & 0.08 & 0.82 & 36,075 & 63.70 & 22.00 & 0.2891 & 0.1495 \\
\hline 2010 & 0.0919 & 0.03 & 0.86 & 34,767 & 66.00 & 27.00 & 0.2579 & 0.1480 \\
\hline 2011 & 0.1056 & 0.04 & 0.90 & 35,949 & 64.00 & 44.00 & 0.2534 & 0.1438 \\
\hline
\end{tabular}


Based on empirical data and on the relation of variables in the following tables, we can create some regression models that indicate statistically significant connections between the dependent variable, FDIs net inflows/GDP, and other several independent variables.

Tab.5: Economic indicators and their explanation

\begin{tabular}{|c|c|c|c|}
\hline $\begin{array}{l}\text { Code of the } \\
\text { variable }\end{array}$ & $\begin{array}{l}\text { Economic } \\
\text { Indicator }\end{array}$ & Description & Source of data \\
\hline Y & $\begin{array}{l}\text { FDls net } \\
\text { inflows/GDP }\end{array}$ & $\begin{array}{l}\text { It is the best indicator of the level of net inflows of foreign } \\
\text { investment in the economy. }\end{array}$ & World Bank \\
\hline $\mathrm{X} 1$ & $\begin{array}{l}\text { Economic } \\
\text { Growth }\end{array}$ & $\begin{array}{l}\text { Increase in \% of GDP. Grogan and Moers (2001), found a } \\
\text { statistically important relation between economic growth and } \\
\text { FDIs inflows in economies in transition, for the studied period } \\
\text { (from } 1990 \text { to 1998). }\end{array}$ & World Bank \\
\hline $\mathrm{X} 2$ & $\begin{array}{l}\text { OP/GDP (foreign } \\
\text { trade) }\end{array}$ & $\begin{array}{l}\text { The amount of imports and exports of goods and services } \\
\text { (OP) in relation to GDP. According to Wheeler and Mody } \\
\text { (1992), there is a positive relationship between OP and } \\
\text { manufacturing sector and a weak negative correlation with the } \\
\text { electronic sector. }\end{array}$ & World Bank \\
\hline X3 & $\begin{array}{l}\text { Average monthly } \\
\text { wage (in ALL) }\end{array}$ & $\begin{array}{l}\text { As one of the most important voices of the business operating } \\
\text { costs, salary expenses are an attractive factor for foreign } \\
\text { investors when the wage standard is low. Charkrabarti (2001) } \\
\text { concluded that there is a stable connection between average } \\
\text { wages and FDIs. }\end{array}$ & INSTAT \\
\hline$X 4$ & $\begin{array}{l}\text { Index of } \\
\text { Economic } \\
\text { Freedom }\end{array}$ & $\begin{array}{l}\text { This index takes values from } 0 \text { to } 100 \text {. The index itself consists } \\
\text { of } 10 \text { other variables that are weighted. This index measures } \\
\text { the entrepreneurial abilities of a country. Economic freedom } \\
\text { "is the key to creating an environment that allows a virtuous } \\
\text { cycle of entrepreneurship, innovation, and economic growth } \\
\text { and sustained development to flourish (The Heritage } \\
\text { Foundation, THF, p. 2). }\end{array}$ & WHF \& WSJ \\
\hline$x 5$ & $\begin{array}{l}\text { Secure Internet } \\
\text { servers for } 100 \\
\text { inhabitants. }\end{array}$ & $\begin{array}{l}\text { Improved facilities range from simple but protected pit latrines } \\
\text { to flush toilets with a sewerage connection. To be effective, } \\
\text { must swear facilities constructed correctly and properly } \\
\text { maintained. }\end{array}$ & World Bank \\
\hline$x 6$ & $\begin{array}{l}\text { Gross capital } \\
\text { formation/ } \\
\text { GDP }\end{array}$ & $\begin{array}{l}\text { It is a ratio of tax revenues to GDP (in \$). Favourable fiscal } \\
\text { policies encourage both local and foreign business. According } \\
\text { to the study of Egger and Raff (2011), taxes have a significant } \\
\text { effect on attracting FDIs flows. }\end{array}$ & World Bank \\
\hline $\mathrm{X} 7$ & Fiscal Burden & $\begin{array}{l}\text { Servers using encryption technology in Internet transactions. } \\
\text { This indicator is considered as determining for the } \\
\text { technological development of the use of internet. } \\
\text { Technological development and FDIs flows have a significant } \\
\text { positive connection, according to the study of Neuhaus } \\
\text { (2006). }\end{array}$ & World Bank \\
\hline
\end{tabular}

Based on these variables we can create several regression models as shown in the table below. 
Tab. 6: Variables used in the models and their explanations.

\begin{tabular}{|c|c|c|c|}
\hline \multirow{2}{*}{ Variable } & \multicolumn{3}{|c|}{ Econometric Models } \\
\hline & $\mathrm{Y}(\mathrm{l})$ & $\mathrm{Y}(\mathrm{II})$ & $\mathrm{Y}(\mathrm{III})$ \\
\hline \multicolumn{4}{|l|}{$\mathrm{X} 1$} \\
\hline \multicolumn{4}{|l|}{$\mathrm{X} 2$} \\
\hline \multicolumn{4}{|l|}{$\mathrm{X3}$} \\
\hline \multicolumn{4}{|l|}{$\mathrm{X} 4$} \\
\hline \multicolumn{4}{|l|}{$\mathrm{x} 5$} \\
\hline \multicolumn{4}{|l|}{$\mathrm{X} 6$} \\
\hline \multicolumn{4}{|l|}{$\mathrm{X} 7$} \\
\hline \multicolumn{4}{|c|}{$\mathrm{Y}_{1}(\mathrm{I})=\alpha_{0}+\alpha_{2} \mathrm{x}_{2}+\alpha_{3} \log \left(\mathrm{x}_{3}\right)+\alpha_{5} \mathrm{x}_{5}+\alpha_{6} \mathrm{x}_{6}+\alpha_{7} \mathrm{x}_{7}+\varepsilon$} \\
\hline \multicolumn{4}{|c|}{$\mathrm{Y}_{1}(\mathrm{II})=\alpha_{0}+\alpha_{2} \mathrm{x}_{2}+\alpha_{3} \log \left(\mathrm{x}_{3}\right)+\alpha_{4} \log \left(\mathrm{x}_{4}\right)+\alpha_{5} \mathrm{x}_{5}+\alpha_{6} \mathrm{x}_{6}+\alpha_{7} \mathrm{x}_{7}+\varepsilon$} \\
\hline \multicolumn{4}{|c|}{$\mathrm{Y}_{1}(\mathrm{III})=\alpha_{0}+\alpha_{1} \mathrm{x}_{1}+\alpha_{2} \mathrm{x}_{2}+\alpha_{3} \log \left(\mathrm{x}_{3}\right)+\alpha_{5} \mathrm{x}_{5}+\alpha_{6} \mathrm{x}_{6}+\alpha_{7} \mathrm{x}_{7}+\varepsilon$} \\
\hline
\end{tabular}

Note: $\quad \checkmark$ included in the model, $x$ not included in the model.

We represent in table 7 the level of statistical importance for the selected variables, for each model. We observe that all the coefficients are statistically significant.

Tab. 7: Level of statistical importance of selected variables

\begin{tabular}{|l|l|l|l|}
\hline \multirow{2}{*}{ Variable } & \multicolumn{2}{|l|}{ Econometric Models } \\
\cline { 2 - 4 } & $Y(I)$ & & $Y(I I I)$ \\
\hline X1 & & & $-0.109^{\star}$ \\
& & $0.049)$ \\
\hline X2 & $-0.290^{\star \star}$ & $-0.292^{\star \star}$ & $-0.325^{\star \star}$ \\
& $(0.022)$ & $(0.016)$ & $(0.023)$ \\
\hline X3 & $0.267^{\star \star}$ & $0.249^{\star \star}$ & $0.285^{\star \star}$ \\
& $(0.022)$ & $(0.018)$ & $(0.018)$ \\
\hline X4 & & $0.160^{\star}$ & \\
& & $(0.067)$ & \\
\hline X5 & $0.001^{\star \star}$ & $0.001^{\star \star}$ & $0.001^{\star \star}$ \\
& $(0.000)$ & $(0.000)$ & $(0.000)$ \\
\hline X6 & $0.405^{\star \star}$ & $0.407^{\star \star}$ & $0.445^{\star \star}$ \\
& $(0.035)$ & $(0.025)$ & $(0.032)$ \\
\hline X7 & $-0.347^{\star \star}$ & $-0.362^{\star \star}$ & $-0.327^{\star \star}$ \\
& $(0.082)$ & $(0.060)$ & $(0.062)$ \\
\hline Adjusted R2 & 0.996 & 0.998 & 0.998 \\
\hline
\end{tabular}

Note: Numbers in parentheses are tratios. ${ }^{*}$ and ${ }^{* *}$ denote significance at $10 \%$ and $5 \%$, respectively. According to test $F$, the statistical importance is $5 \%$. 


\section{CONCLUSION}

For the hosting country, the existence of FDIs is associated with the introduction of new technologies and more efficient capacities, intake of additional capital in the economy, more advanced technical and managerial skills, increased economic competitiveness (in terms of vertical and horizontal expansion or both), etc. According to UNCTAD (2012), investment of international corporate companies played an irreplaceable role in the globalization process.

In this regard, this study had as main focus to show statistically significant relation of FDIs inflows / GDP, with the main indicators of the Albanian economy. In this study we took 11 years (from 2001-2011), taking into account limitations on obtaining the data. We also did not take into consideration the Albanian economic recession of $1997-1998$, a period with major influential forces in the denaturalization of the variables.

From this study, we conclude that the dependent variable, FDIs inflows / GDP ratio, is negatively correlated with the economic growth (\% GDP), the level of external trade (import and export), fiscal burden, and has a positive correlation with the use of services through internet for every 100 inhabitants, the average wage level, and a positive strong correlation with the level of GDP invested in fixed assets.

Above results emphasize the significant relationship according to theoretical background. We affirm that FDIs in Albania will create possibilities for the development of businesses (local enterprises), and improve the standard of living in the country. They will reduce the level of unemployment in Albania, and improve the infrastructure standards and conservation of the environment. They will also affect positively the growth, the organization and the connection of market parts and will contribute to the consolidation of the whole national economy.

\section{BIBLIOGRAPHY:}

Bank of Albania. (July 2012). Foreign Direct Investment Report, 2011.

Bevan, A. A., \& Estrin, S. (24 August 2004). "The determinants of foreign direct investment into European transition economies". Journal of Comparative Economics .

Brooks, C. (2008). Introductory Econometrics for Finance (ed. II ed.). Cambridge: Cambridge University Press.

Buthe, T., \& Milner, H. V. (October 2008). The Politics of Foreign direct Investment into Developing Countries: Increasing FDls through International Trade Agreements? American Journal of Political Science , Vol. 52 (No. 4), Pp. 741-762.

Candela, R. A. (September 2009). "Less Developed Countries, Tourism Investment and Local Economic Development". Bologna, Italy.

Demirhan, E., \& Masca, M. (2008). Determinants of Foreign Direct Investment Flows to Developing Countries: A CrossSectional Analysis. Prague, Economic Papers , 356-369.

Egger, P., \& Horst, R. (September 2011). "Tax Rate and Tax Base Competition for Foreign Direct Investment". Kiel Institute for the World Economy and CESifo, Working Papers.

Ekholm K., J. R. (May 2002). "Foreign direct investment and EU-CEE integration". Copenhagen: Centre for Economic and Business Research, CEBR, Working Paper.

IMF. (November 2012). Albania: 2012 Article IV Consultation.

KPMG Albania Sh.p.k. (2011). Investment in Albania.

Ltd, A. T. (April 2011). Albania: Strengthening Tourism Statistics and Development of a Tourism Satellite Account. Tirana, Albania.

Merier, L. (n.d.). Factors Driving U.S. Foreign Direct Investment. Center For Research in Economics \& Strategy, Washington University .

Ministry of Economy, Trade and Energy of Albania. (May 2012). The Report of FDIs in Albania in 2011.

Ministy of Foreign Affairs of Albania. (December 2006). Agreement for Amendment and Expand Free Trade. Bucharest.

Petranov, S. (2003). "Forign Direct Investments to Bulgaria". Sofia, Bulgaria: Agency for economic analysis and forecasting. 
Pournarakis, M., \& C.Varsakelis, N. (August 2004). Institutions, internationalization and FDIs: the case of economics in transition. Transnational Corporations, Vol. 13 (No. 2), 78-94.

Ranjan, V., \& Agrawal, G. (October 2011). FDIs inflow Determinants in BRIC countries: A Panel Data Analysis. International Business Research, Canadian Center of Science and Education, Vol. 4 (No. 4).

Sanchez-Robles, B., \& Bengoa, M. (July 2002). Foreign direct investment, economic freedom and growth: new evidence from Latin America".

Shahini, B., Mustafaj, I., \& Rexhepi, P. (Shkodra, December 2009, ). The linkeage between politics and investment: How do they help each other?

Tiwari, A. (June 2011). Tourism, Expoerts and FDls as a Means of Growth: "Evidence from four Asian Countries". The Romanian Economic Journal (XIV, No. 40), 132-151.

UNCTAD. (2007). FDIs in Tourism: "The Development Dimension". New York and Geneva.

UNCTAD. (2010). Promoting Foreign Investment in Tourism. New York and Geneva.

UNCTAD. (2012). Trade and Development Report, 2012. New York and Geneva.

UNCTAD. (June 2012). World Investment Report 2012: "Towards a New Generation of Investment Policies". New York and Geneva.

World Bank. (2013). Economy Profile for Albania: "Doing Business 2013".

World Bank. (May 2012). Report on Foreign Direct Investment in Albania, 2011.

Zoran Ivanovic, S. B. (May 2011). Influence of foreign direct investment on tourism in Croatia. UTMS Journal of Economics , 21-28. 